\title{
Exploring the mediation effect of social media acceptance on the relationship between entrepre- neurial personality and entrepreneurial intention
}

\author{
Ben-Roy Do ${ }^{a}$, Alaleh Dadvaria and Massoud Moslehpour ${ }^{b^{*}}$
}

${ }^{a}$ Department of Business Administration, National Central University, Taoyuan, Taiwan ${ }^{b}$ Department of Business Administration, Asia University, Taichung, Taiwan

\section{H R O N I C L E}

\section{Article history:}

Received: June 26, 2020

Received in revised format:

June 302020

Accepted: July 26, 2020

Available online:

July 26,2020

Keywords:

Entrepreneurial personality

Entrepreneurial intention

Technology acceptance model

Social media

Entrepreneurial networking

\section{A B S T R A C T}

As social media becomes influential in our daily life, successful adoption of it may act as a motivating factor to achieve entrepreneurial outcomes such as entrepreneurial intention, the most reliable indicator of actions toward entrepreneurial behavior. Although numerous studies found personality as a strong determinant of entrepreneurial intention, the focus was on broad personality constructs such as the Big Five, rather than specific ones that may predict entrepreneurial outcomes better. Based on the concept of entrepreneurial intentionality and entrepreneurial networking, social media technology acceptance that includes perceived usefulness, perceived ease of use, and intention to use social media, is proposed to mediate the relationship between entrepreneurial personality and entrepreneurial intention. Using a sample of 261 college students and SEM analysis, significant positive direct and indirect influences were found.

\section{Introduction}

Social media, as a group of internet-based technologies, has become a significant part of an individual's life (Tess, 2013; Zhang et al., 2019). Indeed, accessibility of social media platforms anytime from anywhere transformed them to become potential tools to support and benefit different activities among users in a large variety of approaches; such as collaborative learning and creativity ( $\mathrm{Wu}$ et al., 2017), creation of knowledge sharing communities, and establishing entrepreneurial enterprises (Soto-Acosta et al., 2017), global citizenship identification and prosocial outcomes (Lee et al., 2017) and marketing (Moslehpour et al., 2020). Nevertheless, the potential of using social media networks as the mutuality of actor intention to facilitate entrepreneurship is rarely studied. Entrepreneurial intention is considered the most reliable indicator of future entrepreneurial behavior, especially when behavior is difficult to observe (Krueger et al., 2000). It directs an individual's intent toward target behavior (Krueger, 2007; Obschonka et al., 2010; Do \& Dadvari, 2017). Studies on entrepreneurial intention represent several factors to relate to the individual's intention to engage in venture creation, including individual personality, externals, and environmental context. Drawing on Ajzen's (1991) theory of planned behavior, as intention predicts action, certain characteristics predict and affect intention. Following Zhao and Seibert (2006), personality must be considered as a significant part of any dimensional model related to entrepreneurial activity and new venture creation. This has led to the mentality that personality traits may influence entrepreneurial outcomes via contextual and motivational factors (Karimi et al., 2017). According to the concept of entrepreneurial intentionality (Bird and Jelinek, 1988), to affect entrepreneurial intention, a combination of both personality and contextual factors are required (Krueger et al., 2000; Schlaegel \& Koenig, 2014). Although previous studies suggested personality as a strong determinant of entrepreneurial intention (Crant, 1996; Obschonka 
et al., 2010), the focus was on broad personality constructs, such as the Big Five personality dimensions. Nevertheless, contemporary research on personality and entrepreneurship suggests that to measure entrepreneurial success, narrow personality traits can predict entrepreneurial outcomes better than broad traits (Leutner et al., 2014). Notwithstanding, the role of contextual factors in measuring these mediating relationships to affect entrepreneurial intention is worth exploring. In terms of contextual factors, we proposed social media acceptance as a possible mediator to influence the effect of entrepreneurial personality on entrepreneurial intention. We assume the potentiality of social media acceptance in relation to humans will lead to a set of activities. Social media technology acceptance is based on the technology acceptance model (TAM), that is, the intention to use social media. TAM predicts user acceptance of technology-based upon the estimation of perceived usefulness (PU), perceived ease of use (PEoU), and intention to use that technology (IU) (Svendsen et al., 2013; Schmidthuber et al., 2020). Although there have been several studies that examined the relationship between personality variables and social media usage (Hughes et al., 2012; Ross et al., 2009; Ryan \& Xenos, 2011), there has been no attention devoted to entrepreneurial personality and social media technology acceptance. Therefore, this study contributes to the debate by developing a conceptual model that includes personality, and external contextual factor in specifying their associations with entrepreneurial intention, and further explore the influence of social media acceptance on the link between personality and intentional behavior to analyze how the adoption of social media may affect users themselves. Additionally, in response to the criticism raised by early studies that challenge the capability of personality trait as the sole indicator of entrepreneurial intention, a new concept of entrepreneurial personality is employed in the proposed model. Importantly, the entrepreneurial personality-intention relationship will be investigated under the scope of the entrepreneurial network (Engel et al., 2017), which refers to the unique networking styles, processes, or strategies entrepreneurs do in shaping and creating network ties by applying an affordance lens to test the capability of social media acceptance in relation with human potentiality. Moreover, as responding to the rapid technological move, social media acceptance is explored not only in terms of social media usage, but also the usefulness, ease of use, and intention to use social media toward the entrepreneurial intention. Findings provide a more comprehensive view not only to predict highly inclined future entrepreneurs but also to underscore the significance of practical applications for better e-learning systems and training to motivate individual entrepreneurial intention. Realizing the potentiality of social media on human action, while considering entrepreneurial personality, can provide new insights into understanding the strengths, and weaknesses of future entrepreneurs before confronting the uncertain challenges of starting a new venture.

\section{Literature review and theoretical background}

\subsection{Entrepreneurial intention}

Entrepreneurship could be defined as the discovery and exploration of an opportunity to result in entrepreneurial outcomes, which would be best predicted by entrepreneurial intention (Liñán et al., 2011; Nga \& Shamuganathan, 2010; Elston \& Weidinger, 2018). A growing body of research indicates intentionality as the core aspect of human beings that constitute a path for an individual's future performance, that is, entrepreneurial action following the formation of entrepreneurial intention (Douglas, 2013; Zhang et al., 2014). Entrepreneurial intention is described as an attentive state of mind that relates to an individual's willingness or disposition towards an entrepreneurial goal, such as venture creation (Krueger et al., 2000). Given that forming an intention is the first fundamental step, it is sensible to analyze how entrepreneurial intention as a determinant factor towards performing entrepreneurial actions (Krueger et al., 2000; Liñán et al., 2011). Prior research on predictors of entrepreneurial intention suggested personality is a significant predictor of entrepreneurial intention. For instance, Wang and Wong (2004) explained the entrepreneurial interest of adults based on personal background. In line with this assumption, some personality characteristics such as innovation or creativity, proactivity, risk-taking, and openness to experience are addressed as key elements to predict entrepreneurial intention (Zhao et al., 2010). An individual with certain personality traits may be more attracted to entrepreneurial behavior. Thus in the future, they may persist in establishing the new venture.

\subsection{Entrepreneurial personality}

According to Bird's (1988) concept of entrepreneurial intentionality, a combination of both personality and contextual factors are required to structure entrepreneurial intention (Bird, 1988; Krueger et al., 2000; Obschonka et al., 2019; Schlaegel and Koenig, 2014). Personality construct is often suggested as a significant predictor of entrepreneurial intention (Crant, 1996). Within the context of entrepreneurial studies, personality is often taken into account (Brandstätter, 2011; Leutner et al., 2014; One's et al., 2007). However, explaining the link between personality and entrepreneurial intention is focused on the framework of the broad, Big Five personality traits. For instance, a meta-analysis conducted by Zhao and Seibert (2006) found that entrepreneurs scored higher on conscientiousness and openness to experience, and lower on neuroticism and agreeableness. Another meta-analysis by Zhao, Seibert, and Lumpkin (2010) found a moderate effect size for entrepreneurial intentions (multiple $\mathrm{R}=.36$ ) and entrepreneurial performance (multiple $\mathrm{R}=.31$ ). Recently, Leutner et al. (2014) showed that narrow traits are more reliable predictors of entrepreneurial outcomes, as these traits matched to the knowledge, skills, and abilities relevant in entrepreneurship. Given that entrepreneurial outcomes are emphasizing on opportunities over threats (Eckhardt and Shane, 2003), some characteristics are identified among the most important ones to start entrepreneurial activities, including opportunity recognition, opportunity exploitation, innovation, and value creation (Ardichvili et al., 2003; Cuesta et al., 2018). Based on this notion, Ahmetoglu et al. (2011) developed the Measure of Entrepreneurial Tendencies and Abilities (META) to measure entrepreneurial opportunism (EO), entrepreneurial proactivity (EA), entrepreneurial vision (EV), and entrepreneurial creativity (EC). In the Leutner et al. (2014) study, all four facets loaded onto a latent META total factor, which 
were found to predict total entrepreneurial activity, a combination of entrepreneurial success outcomes. Therefore, it is proposed that:

$\mathbf{H}_{1}$ : Entrepreneurial personality is positively related to entrepreneurial intention.

\subsection{Social media technology acceptance}

As prior research suggested entrepreneurial intention may be indirectly influenced by personal, social and situational factors (Krueger et al., 2000), we proposed social media technology acceptance as a possible mediator to influence the effect of entrepreneurial personality on entrepreneurial intention. Based on the new theory of entrepreneurial intentionality proposed by Mishra and Zachary (2014), opportunities without intention are meaningless, and the interaction between opportunities and intentions necessarily should be considered. Social media, a group of Internet-based application that allows interaction among people in which they create value and exchange content (Kaplan and Haenlein, 2010; Zhang et al., 2015), offers the context and opportunity for entrepreneurs to participate in a collaborative manner (Laroche et al., 2012). The use of social media can be considered as a component of entrepreneurial networking, which refers to the networking styles, strategies, or processes of entrepreneurs (Engel et al., 2017). Entrepreneurial networking is not only about individuals thinking of new venture creation, but also to the utilization of society for social and economic change (Obschonka et al., 2015). In the social media network of the entrepreneurial community, individuals with multi-skills in different areas, such as physical, financial, managerial, and entrepreneurial experience are more likely to be found (Stuetzer et al., 2013), and consequently more resourceful to combine different resources to run the business successfully. Given that entrepreneurial ventures are known as the primary source of employment, economic growth, technological development (Acs and Szerb, 2007; Wennekers and Thurik, 1999), understanding the influence of social media technology acceptance on entrepreneurial personality and entrepreneurial intention is theoretically and practically relevant. Social media technology acceptance refers to the basics of the technology acceptance model (TAM) to social media (Dadvari and Do, 2019; Devaraj et al., 2008; Al-Qaysi et al., 2018; Pourkhari et al., 2019). Perceived usefulness (PU) refers to the individual's perception of applying specific social media technology. Perceived ease of use (PEoU) is defined as the degree to which an individual believes using a particular system of social media would be free of effort. Finally, the intention to use that technology (IU) refers to an individual's intention to use specific social media technology. TAM is an adoption of the theory of reasoned action (Ryan and Xenos, 2011), where personality can lead to beliefs related to the behavior. According to Davis (1993), perceived usefulness is 50\% more influential than ease of use. In entrepreneurial networking, entrepreneurs participate as individual actors to drive the social network change in a dynamic process (Emirbayer and Goodwin, 1994; Hoang and Antoncic, 2003; Slotte-Kock and Coviello, 2010). As entrepreneurs can, and often do, break away from their existing network structures (Hallen and Eisenhardt, 2012; Porter and Woo, 2015), for social media to work in entrepreneurial networking, entrepreneurs need to recognize and accept social media technology as beneficial to entrepreneurial activities. Based on TAM, PU and PEoU are affected by external variables such as user traits and organizational elements (Zaremohzzabieh et al., 2015). Personality is associated with technology in different ways, such as human-computer interaction (Svendsen et al., 2013). Considering that personality can be described as an individual response to a particular situation (Borghans et al., 2011; Roberts, 2009), social media offers a particular situation, and social media technology acceptance indicates the belief of social media in facilitating entrepreneurial networking. Therefore, the following hypotheses are proposed:

$\mathbf{H}_{2 \mathbf{a}}$ : Entrepreneurial personality is positively related to the perceived usefulness of social media.

$\mathbf{H}_{2 \mathbf{b}}$ : Entrepreneurial personality is positively related to perceived ease of use of social media.

$\mathbf{H}_{2 \mathrm{c}}$ : Entrepreneurial personality is positively related to intention to use social media.

The general finding using technology acceptance model suggests external variables, such as personality, maybe fully mediated by perceived usefulness and perceived ease of use, and both contribute to technology usage (Devaraj et al., 2008; Svendsen et al., 2013; Zaremohzzabieh et al., 2015). Furthermore, sub-dimensions of TAM were generally found to influence each other (Davis, 1989; Davis et al., 1989). For instance, perceived usefulness may mediate perceived ease of use toward behavioral intention to use technology, and consequently, the adoption of services such as e-government (Horst et al., 2007) and smartphones (Joo and Sang, 2013). Therefore, it is proposed that:

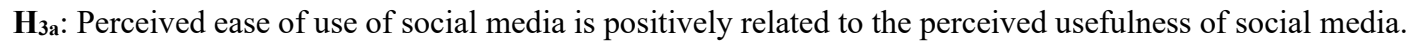

According to studies applying TAM in a different context, perceived usefulness is positively correlated to use the system (Baker-Eveleth and Stone, 2015; Chen et al., 2013). For example, Horton et al. (2001) confirmed the existence of a positive influence of PU on the intention to use intranet media. Park et al. (2014) asserted that PU is positively associated with technology interest (Park and Kim, 2014; Park et al., 2014). Therefore, it is proposed that:

$\mathbf{H}_{\mathbf{3} \mathbf{b}}$ : Perceived usefulness of social media is positively related to intention to use social media.

Similarly, perceived ease of use is found to be the other determinant of system intention. In other words, if a system is relatively easy to use, an individual will be more willing to learn about its feature (Park et al., 2014). Studies revealed that there is a positive relationship between PEoU and behavioral intention. For instance, Wang et al. (2003) found perceived ease of use is a significant antecedent of mobile banking. Several studies in line with prior research with TAM, it is hypothesized that:

$\mathbf{H}_{3 \mathbf{c}}$ : Perceived ease of use of social media is positively related to intention to use social media. 
While PU and PEoU are considered to be the two critical determinants of technology acceptance, the attitude toward the use of technology may influence other outcome variables. For instance, in the Zaremohzzabieh et al. (2015) study, they found empirical support that attitude may serve as a mediator toward the entrepreneurial intention. Indeed, TAM postulates that a user's acceptance of the technology system is influenced by the user's intention to use the system, which in turn influenced by the user's attitude toward the system (Zaremohzzabieh et al., 2016). In the present study, the intention to use social media is the positive attitude toward social media influenced by PU and PEoU. Based on H3a and H3b, it is hypothesized that:

$\mathbf{H}_{4}$ : Intention to use social media is positively related to entrepreneurial intention.

\subsection{Mediation of social media technology acceptance}

While previous research has studied the link between personality and social media on platforms such as Facebook and Twitter (Hughes et al., 2012; Legris et al., 2003; Ryan \& Xenos, 2011), the emphasis was on the attitude and individuals beliefs towards the new technology, rather than whether the technology acceptance may influence entrepreneurial intention. Individual difference variables are known as the key to the successful implementation of new technology. Prior research found the Big Five personality traits to be related to specific beliefs about the perceived usefulness and perceived ease of use of technology (Devaraj et al., 2008; Moslehpour et al., 2018; Svendsen et al., 2013), and its mediating effect on social media use (Kwon and Wen, 2010). Therefore, it is proposed that:

H5: Perceived usefulness of social media mediates the relationship between entrepreneurial personality and intention to use social media.

H6: Perceived ease of use of social media mediates the relationship between entrepreneurial personality and intention to use social media.

Based on the entrepreneurial networking (Engel et al., 2017) and the new theory of entrepreneurial intentionality (Mishra and Zachary, 2014), we propose that in addition to attitude or beliefs toward social media, social media technology acceptance can have a significant consequence on entrepreneurial intention. The rationale is based on Shapero's intention model, which hypothesized that perceived values are key factors that affect intention. Research on the intention to use technology has found the mediation effect of perceived value on user intention to pay (Lu and Hsiao, 2010; Ngai et al., 2015). Moreover, prior research also suggests that an individual inclination to entrepreneurship is indirectly influenced by the experience received through the environment (Peterman and Kennedy, 2003; Schlaegel and Koenig, 2014). In this instance, social media technology acceptance can be considered to provide the experience and perceived value to entrepreneurs, and consequently influence their entrepreneurial intention. Therefore, it is hypothesized that:

$\mathbf{H}_{7}$ : Intention to use social media mediates the relationship between entrepreneurial personality and entrepreneurial intention.

The proposed research model is shown in Fig. 1 below.

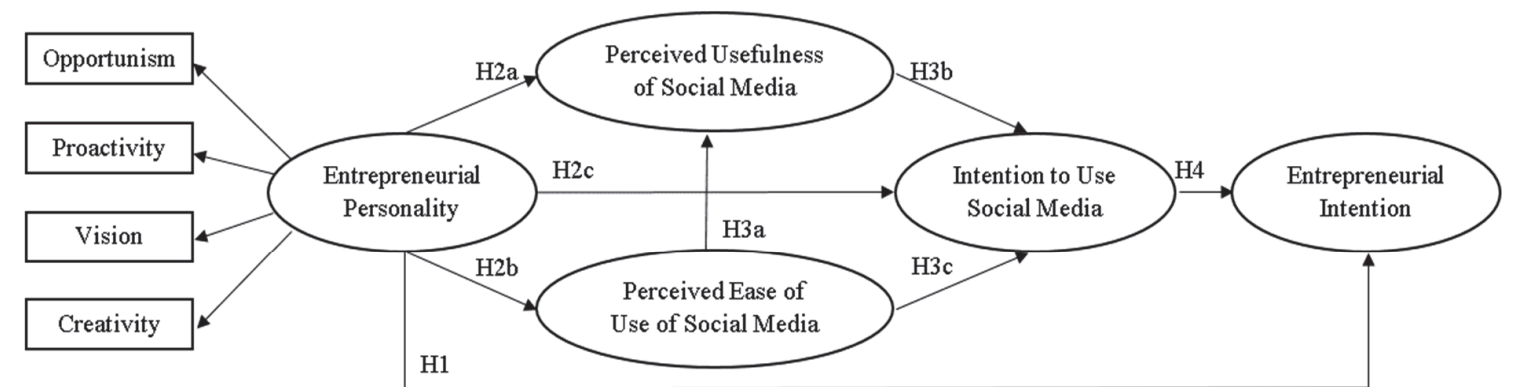

H5: Perceived usefulness of social media mediates the relationship between entrepreneurial personality and intention to use social media H6: Perceived ease of use of social media mediates the relationship between entrepreneurial personality and intention to use social media H7: Intention to use social media mediates the relationship between entrepreneurial personality and entrepreneurial intention

Fig. 1. Research framework

\section{Research methodology}

\subsection{Data collection}

A total of 265 undergraduate students taking business administration related courses at a large public university in Taiwan were recruited. While about $50 \%$ of participants were business majors, students from fields outside of management, such as liberal arts, science, and engineering. The decision to use student sample is intentional and considered appropriate to be consistent with previous studies where future entrepreneurs are not necessarily those who have business background (Hmieleski and Lerner, 2016; Krueger et al., 2000). Furthermore, undergraduate students represent a dynamic segment of the population in the digital era, where they grew up with high social media immersion and may enjoy the benefit of networking with entrepreneurial talent regionally and globally. Finally, the student sample provides better control in terms of the completion of questionnaires (Díaz-García and Jiménez-Moreno, 2010). According to a National Development Council survey, among 
young adults in Taiwan, the Internet penetration rate is $82.3 \%$, with more than $60.1 \%$ of online tasks were through social media (Chen and Yen, 2018). To reduce the influence of common method bias (CMB), we employed several alternatives suggested by Podsakoff et al. (2003). Before data collection, pre-validated scales were chosen, mixed and limited reversed items were used. A representative group of respondents pretested the survey instrument. Furthermore, the participant's identity was protected to ensure anonymity and voluntary participation. After the elimination of incomplete questionnaires, the data set of 261 respondents was created. Participants were aged 18 to 24 years old. The sample consisted of 135 (51.7\%) males and $126(48.3 \%)$ females with a mean age of $20.55(\mathrm{SD}=1.15)$. All of the participants confirmed their usage of social media in daily life. Among them, only $1.1 \%$ have declared a strong desire to start a new venture creation, which represents a low level of entrepreneurial intention. However, $4.6 \%$ of the population were highly intended to use social media. $43.7 \%$ were strongly agreed that the smartphone is the preferred device, and 55.6\% have shown great intention to use Facebook.

\subsection{Measurement and scaling}

The measurement scales for all studied constructs were derived from extant validated scales. Theoretical construct items were measured with a five-point Likert scale ranging from $1=$ strongly disagree to $5=$ strongly agree. The questionnaire includes three measures. Entrepreneurial personality was adapted from the measure of entrepreneurial tendencies and abilities (META) developed by Ahmetoglu, Leutner, and Chamorro-Premuzic (2014). This scale contains 44 items, with four domains of entrepreneurial personality traits (11 items each): Entrepreneurial opportunism (EO; 'I can easily spot trends and new opportunities'), entrepreneurial proactivity (EA; 'I persist even in the face of adversity'), entrepreneurial vision (EV; 'I am motivated to change things for the better'), and entrepreneurial creativity (EC; 'I identify and solve problems in new ways') (Leutner et al. 2014). The composite score was calculated by summing across items. Entrepreneurial Intention (EI) was measured with a six-item scale developed and validated by Liñán and Chen (2009). The technology acceptance model with perceived usefulness, perceived ease of use, and intention to use technology was measured using items adapted from Davis (1989). A total of 13 items were used to assess the level of technology acceptance using social media, with five items each for perceived usefulness and perceived ease of use, and three items for intention to use social media (Davis, 1989). All the measurement items originated from English language works, but the study was conducted in Taiwan, where the official language is Chinese. The scale items were translated using a back-translation technique to ensure that item meaning was preserved through the translation process.

\section{Results}

Descriptive statistics and correlations are presented in Table 1. As expected, entrepreneurial personality correlated significantly with entrepreneurial intention, as well as with each construct of the technology acceptance model. Intention to use social media is significantly correlated with all other variables. Final values for composite reliability (CR) and Cronbach's alpha both exceed 0.7 , representing satisfactory reliability and internal consistency.

Table 1

Mean, standard deviation, and correlation of study variable

\begin{tabular}{|c|c|c|c|c|c|c|c|}
\hline Variable & $\mathrm{M}$ & $\mathrm{SD}$ & $\alpha$ & 1 & 2 & 3 & 4 \\
\hline 1. Entrepreneurial Personality (EP) & 3.303 & .367 & .899 & - & & & \\
\hline 2. Perceived Usefulness (PU) & 3.877 & 690 & .808 & .095 & - & & \\
\hline 3. Perceived Ease of Use (PEoU) & 3.507 & .700 & .808 & $.186^{* *}$ & $.195^{* *}$ & - & \\
\hline 4. Intention to Use Social Media (IU) & 3.441 & .814 & .823 & $.205 * *$ & $.503 * *$ & $.321 * *$ & - \\
\hline 5. Entrepreneurial Intention (EI) & 2.902 & .822 & .927 & $.261 * *$ & $.122 *$ & $.392 * *$ & $.244 * *$ \\
\hline
\end{tabular}

Note. $\mathrm{N}=261 . * p<.05 . * * p<.01$

Also, the convergent validity of the measurement model was assessed by CR, as well as the average variance extracted (AVE). $\mathrm{CR}$ was used to test the degree to which the indicator variables converge and share a portion of the variance. All the CR values have surpassed the threshold, that is .7. Similarly, AVE was applied to measure the level of variance captured by the construct versus the level due to measurement error. A common rule of thumb suggested threshold of .5 is acceptable (Hair et al., 2010). Accordingly, discriminant validity is established by observing the AVE values of each construct to be greater than maximumshared variance (MSV). Convergent validity and discriminant validity were satisfactory. Construct validity indicates that measurement items are reliable to reflect the corresponding constructs. With CR $>$ AVE, AVE $>.5$, MSV $<$ AVE, and ASV $<$ AVE, validation requirements have been achieved. Composite reliability and validity are shown in Table 2.

Table 2

Composite reliability, convergent validity, and discriminative validity

\begin{tabular}{llll}
\hline Variable & CR & AVE & MSV \\
\hline 1. Entrepreneurial Personality (EP) & .802 & .505 & .182 \\
2. Perceived Usefulness (PU) & .830 & .620 & .458 \\
3. Perceived Ease of Use (PEoU) & .774 & .533 & .312 \\
4. Intention to Use Social Media (IU) & .828 & .618 & .138 \\
5. Entrepreneurial Intention (EI) & .936 & .746 & .148 \\
\hline
\end{tabular}

The current study applied structural equation modeling (SEM) using Amos 22.0. For evaluation of model fit, Chi-square statistic $\left(\chi^{2}\right), \chi^{2} / \mathrm{df}$ ratio, root mean square error of approximation (RMSEA), and comparative fit index (CFI) were used (Shook et al., 2004). The initial measurement model showed moderate fit $\left(\chi^{2}=295.941\right.$, df $=125, \mathrm{CMNI} / \mathrm{DF}=2.368, \mathrm{CFI}=.934$, 
RMSEA $=.073$, and NFI $=.893$ ). However, by removing an item from perceived usefulness of social media, and an item from perceived ease of use of social media with low factor loadings, the measurement model demonstrated better statistics, with $\chi^{2}$ $=23.115(\mathrm{df}=16), \mathrm{CMNI} / \mathrm{DF}=1.445, \mathrm{CFI}=.985, \mathrm{RMSEA}=.041$, and NFI $=.955$, suggested a significantly adequate and sufficient fit to the data. In the absence of mediator, the total direct path coefficient from entrepreneurial personality to entrepreneurial intention was significant, and H1 was supported $(\beta=.964, z=3.984, p<.001)$. H2 hypothesized that entrepreneurial personality is positively related to social media technology acceptance, in terms of perceived usefulness of social media (H2a), perceived ease of use of social media $\left(\mathrm{H}_{2 \mathrm{~b}}\right)$, and intention to use social media $\left(\mathrm{H}_{2 \mathrm{c}}\right)$. $\mathrm{H} 2 \mathrm{a}(\beta=.321, z=2.212, p<.05), \mathrm{H} 2 \mathrm{~b}$ $(\beta=.463, \mathrm{z}=6.540, p<.001)$, and $\mathrm{H}_{2 \mathrm{c}}(\beta=.139, z=2.193, p<.05)$ were all supported. $\mathrm{H} 3$ tested the relationship among components of social media technology acceptance, where H3a tested PEoU of social media on PU of social media $(\beta=.125$, $z=2.173, p<.05)$, H3b tested PU of social media on intention to use social media $(\beta=.531, z=8.590, p<.05)$, and H3c tested PEoU of social media on intention to use social media $(\beta=.201, z=2.584, p<.05)$. Consistent with previous studies, $\mathrm{H} 3$ family of hypotheses were fully supported. $\mathrm{H} 4$ proposed intention to use social media is positive related to entrepreneurial intention $(\beta=.152, z=2.541, p<.05)$ was supported as well. The results for direct path is shown in Table 3.

Table 3

Hypothesis testing for direct path

\begin{tabular}{|c|c|c|c|c|}
\hline Path & Estimate & C.R. & $p$ & Result \\
\hline $\mathrm{EI} \leftarrow \mathrm{EP}$ & .964 & 3.984 & .001 & H1: Significant \\
\hline $\mathrm{PU} \leftarrow \mathrm{EP}$ & .321 & 2.212 & .032 & H2a: Significant \\
\hline $\mathrm{PEoU} \leftarrow \mathrm{EP}$ & .463 & 6.540 & .001 & H2b: Significant \\
\hline $\mathrm{IU} \leftarrow \mathrm{EP}$ & .139 & 2.193 & .038 & H2c: Significant \\
\hline $\mathrm{PU} \leftarrow \mathrm{PEoU}$ & .125 & 2.173 & .030 & H3a: Significant \\
\hline $\mathrm{IU} \leftarrow \mathrm{PU}$ & .531 & 8.590 & .004 & H3b: Significant \\
\hline $\mathrm{IU} \leftarrow \mathrm{PEoU}$ & .201 & 2.584 & .001 & H3c: Significant \\
\hline $\mathrm{EI} \leftarrow \mathrm{IU}$ & .152 & 2.541 & .030 & H4: Significant \\
\hline
\end{tabular}

Hypotheses 5 to 7 deal with the mediation effect of social media technology acceptance, the indirect effect of the independent variable (i.e., entrepreneurial personality) on the outcome variable (i.e., entrepreneurial intention) that goes through the mediator. Using the traditional approach without mediation, the direct effect of entrepreneurial personality toward the intention to use social media was significant $(\beta=.730, p<.001)$. However, after adding PU of social media into the model, the beta coefficient dropped to $\beta=.553(p<.001)$, yet the path coefficient from entrepreneurial personality to intention to use social media remained significant. This suggests the indirect path was significant, and H5 was supported. Similarly, adding PEoU of social media into the model showed $\beta=.241(p<.05)$, and H6 was supported as well. Finally, whether the effect of entrepreneurial personality on entrepreneurial intention is influenced by the mediation of social media technology acceptance was tested. Results indicated that beta coefficient has dropped from $\beta=.694$ to $\beta=.590(p<.001)$, and H7 was supported. The significance of the mediating effect was tested using the bootstrap estimation procedure. To confirm mediation, bootstrap confidence interval provides the best estimation in testing for mediation effect (Cheung \& Lau, 2008). Bootstrapping is a nonparametric approach to hypothesis testing that makes no assumption about the shape of the distribution of the variable and provides an accurate estimation of the indirect effect (Preacher \& Hayes, 2004). Using 2000 bootstrap samples, the mediation of PU showed the confidence interval for the indirect effect was .025 to .325 . Thus, the mediated effect of PU on the intention to use social media was significantly different from zero at the .05 level $(p=.027)$, and H5 was supported. Similarly, the confidence interval for the mediation of PEoU was .080 to .509 , which was also significantly different from zero at the .05 level $(p=.008)$, and H6 was supported. Finally, the confidence interval for the mediation of intention to use social media was .005 to .233 , did not contain zero and was significant at the .05 level $(p=.040)$. To sum up, the results of the mediation has been confirmed by the bootstrapping procedure. The unstandardized indirect path coefficient is displayed in Table 4, and the structural equation model is shown in Fig. 2.

Table 4

The results of bootstrapping in testing the mediation effect

\begin{tabular}{|c|c|c|c|c|}
\hline Path & Estimate & $p$ & Result & Type of Mediation \\
\hline $\mathrm{IU} \leftarrow \mathrm{PU} \leftarrow \mathrm{EP}$ & .177 & .027 & H5: Significant & Partial \\
\hline $\mathrm{IU} \leftarrow \mathrm{PEoU} \leftarrow \mathrm{EP}$ & .273 & .008 & H6: Significant & Partial \\
\hline $\mathrm{EI} \leftarrow \mathrm{IU} \leftarrow \mathrm{EP}$ & .095 & .040 & H7: Significant & Partial \\
\hline
\end{tabular}

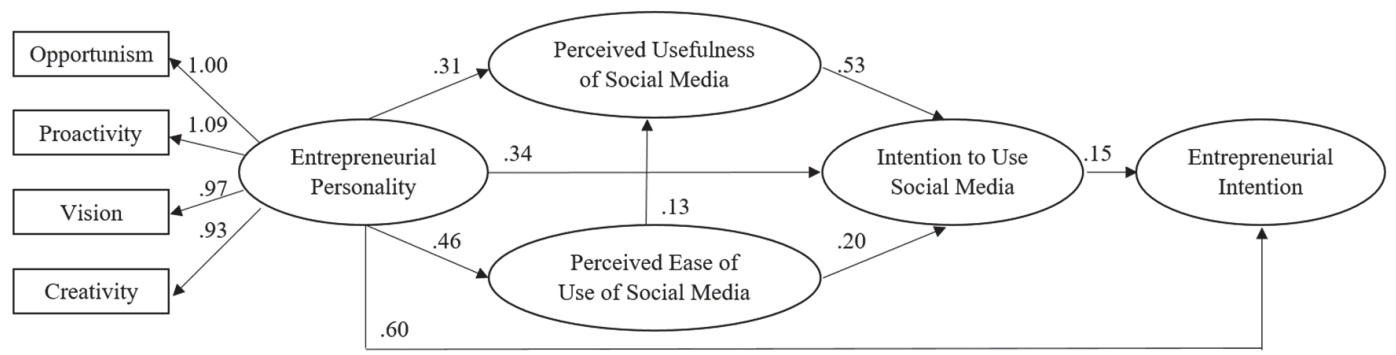

Fig. 2. Structural equation model (unstandardized coefficients) 


\section{Discussion and conclusion}

Recent research in the field of entrepreneurial personality has emphasized that narrow personality traits are better indicators of entrepreneurial outcomes. Contributing to the existing literature, the present study is the first and only study to consider the mediation of social media technology acceptance and entrepreneurial intention. Given the vital role of entrepreneurial personality as a part of the economic engine, besides aiming at a better understanding of the roles of effect in user technology acceptance, it is sensible to analyze the factors, which can influence individuals during the decision-making process toward entrepreneurial activities. Drawing upon previous findings, the present study developed a conceptual research model and empirically tested several hypotheses about the influence of social media technology acceptance on the relationship between entrepreneurial personality and entrepreneurial intention. Findings have revealed that perceived usefulness of social media, as well as perceived ease of use of social media, both can positively and significantly mediate how entrepreneurial personality related to entrepreneurial intention. This is consistent with the research findings that show the mediating role of value perception toward interacting behavior with social media (Davis, 1989; Sun \& Zhang, 2008), Findings of the model revealed that $\mathrm{PU}$ and PEoU significantly influenced the inclination toward technology and this is consistent with previous TAM studies. In other words, when individuals with strong entrepreneurial personalities assume a higher level of technology usefulness and system ease of use, these future entrepreneurs are more likely to use that specific technology. More importantly, this model demonstrated that an individual with higher intention towards social media technology usage has a higher potential for entrepreneurial activities. Within the field of entrepreneurial studies, entrepreneurs' theory of production proposes that entrepreneurs will recognize and employ technologies that result in the improved procedure (Zaremohzzabieh et al., 2016). In this regard, the effect of PU on intention toward social media technology is another evidence to support the effectiveness of technological adaptability, in particular during the decision-making process toward entrepreneurial activities. However, according to the theory of entrepreneurial intentionality, the developmental process that encompasses entrepreneurial intention is relative to individuals thinking, acting, and adaptability (Mishra \& Zachary, 2014). Therefore, the adoption of new technologies as the environmental social change will influence entrepreneurial networking. Thus, this study resulted in an important finding that has highlighted the role of social media as a new technology platform to mediate the influence of entrepreneurial personality toward the entrepreneurial intention. One practical implication of this study is that the results show that entrepreneurial personality is a valid predictor of entrepreneurial intention. These narrow, specific personality constructs may become useful tools to promote entrepreneurial outcomes. Importantly, this applies not only to those interested to start and run a business but also employees and individuals working in a different creative environment. Organizations can benefit from recruiting entrepreneurial individuals based on their personality profiles (Leutner et al., 2014). This study sheds light on some crucial individual variables as a particular entrepreneurial personality who holds positive beliefs about usefulness and ease of use of social media. Technology acceptance models suggest an intention to use social media is the outcome variable resulted from perceived usefulness and perceived ease of use, which ultimately leads to actual use. This is essential for positions and job environments where using a collaborative system is essential. An organization could benefit from individuals having positive beliefs toward social media. A final implication might arise from individuals facing new technologies as external motivation in the decision-making process toward entrepreneurial outcomes (Devaraj et al., 2008). Understanding entrepreneurial personality and how they perceive new technologies can lead to better change management strategies. As the partial mediation role of technologies has been found, this gives a new direction for future studies to realize entrepreneurial personality and distinctive characteristics involved during the entrepreneurial decision-making process. The outcome, entrepreneurial intention among students, may refer to the efficacy of the training program. Furthermore, regarding the level of technology acceptance among individuals, policymakers can better understand and motivate individuals toward entrepreneurship. Relatively, entrepreneurial plans can be improved through social media technologies to shape intended entrepreneurial behaviors.

\subsection{Limitation and direction for future research}

Although the current study expands the findings of relevant research, it has a few limitations that present promising directions for future studies. One potential limitation might concern the context of the research that was conducted in Taiwan, which may put some restrictions on the generalizability of the results. An interesting methodology would be to select samples from different nations. Although the questionnaire was initially developed in English, translated into Chinese and back-translated to ensure the proper meaning, future research could explore possible cultural differences. Second, the lack of variation in educational attainment is another type of limitation to consider. Recently, some scholars argue that graduate students may exhibit a better representative sample when estimating the student's ability to start a new venture (Shinnar et al., 2018). In the current study, all respondents were college students as potential future entrepreneurs. As the focus was on the assessment of entrepreneurial intention and can be justified (Hmieleski \& Lerner, 2016), whether their entrepreneurial intention may differ from experienced entrepreneurs may deserve a further look. Another limitation is the sample size, which can be more significant to include students from a more diverse background. Finally, investigating intentional behavior may warrant longitudinal research, which is usually ignored by previous research. However, the accelerating change that is referred to as the perceived increase in technology growth may be another factor that can positively or negatively affect the relationship among research variables. The findings of this research enrich our understanding of the role of the technology acceptance model in the entrepreneurship domain. However, evidence in this field of study is rare, and further research is needed. These results are con- 
sistent with previous studies that have indicated the value of social media usage influencing personality traits toward intentional behavior. Given that the technology acceptance basics partially mediate entrepreneurial personality and entrepreneurial intention, future studies should place more emphasis on the benefits of technology acceptance for newer emerging technology that may foster further collaboration in the entrepreneurial networking. Finally, although results suggest that a positive association between intention to use social media and entrepreneurial intentions exists, whether these results would apply to entrepreneurial success remains to be tested for future research.

\section{References}

Acs ,Z. J., \& Szerb, L. (2007). Entrepreneurship, economic growth and public policy. Small Business Economics, 28(2-3), 109-122.

Ahmetoglu, G., Leutner, F., \& Chamorro-Premuzic, T. (2011). EQ-nomics: Understanding the relationship between individual differences in trait emotional intelligence and entrepreneurship. Personality and Individual Differences, 51(8), $1028-1033$.

Ajzen, I. (1991). The theory of planned behavior. Organizational Behavior and Human Decision Processes, 50(2), $179-211$.

Al-Qaysi, N., Mohamad-Nordin, N., \& Al-Emran, M. (2018). A systematic review of social media acceptance from the perspective of educational and information systems theories and models. Journal of Educational Computing Research.

Ardichvili, A., Cardozo, R., \& Ray, S. (2003). A theory of entrepreneurial opportunity identification and development. Journal of Business Venturing, 18(1), 105-123.

Baker-Eveleth, L., \& Stone, R. W. (2015). Usability, expectation, confirmation, and continuance intentions to use electronic textbooks. Behaviour \& Information Technology, 34(10), 992-1004.

Bird, B. (1988). Implementing entrepreneurial ideas: The case for intention. Academy of Management Review, 13(3), $442-453$.

Borghans, L., Golsteyn, B. H., Heckman, J., \& Humphries, J. E. (2011). Identification problems in personality psychology. Personality and Individual Differences, 51(3), 315-320.

Brandstätter, H. (2011). Personality aspects of entrepreneurship: A look at five meta-analyses. Personality and Individual Differences, 51(3), 222-230.

Chen, C. W., Yen, W. (2017). Internet usage in Taiwan up to 82.3 percent. Focus Taiwan News Channel. Retrieved October 10, 2018 from http://focustaiwan.tw/news/asoc/201712290024.aspx.

Chen, S. C., Liu, M. L., \& Lin, C. P. (2013). Integrating technology readiness into the expectation-confirmation model: An empirical study of mobile services. Cyberpsychology, Behavior, and Social Networking, 16(8), 604-612.

Cheung, G. W., \& Lau, R. S. (2008). Testing mediation and suppression effects of latent variables: Bootstrapping with structural equation models. Organizational Research Methods, 11(2), 296-325.

Chua, Y. P., \& Chua, Y. P. (2017). Do computer-mediated communication skill, knowledge and motivation mediate the relationships between personality traits and attitude toward Facebook?. Computers in Human Behavior, 70, 51-59.

Cuesta, M., Suárez-Álvarez, J., Lozano, L. M., García-Cueto, E., \& Muñiz, J. (2018). Assessment of eight entrepreneurial personality dimensions: Validity evidence of the BEPE battery. Frontiers in Psychology, 9.

Crant, J. M. (1996). The proactive personality scale as a predictor of entrepreneurial intentions. Journal of Small Business Management, 34, 42-49.

Dadvari, A., \& Do, B. R. (2019). Modeling Gen Z Continuance Intention toward Ubiquitous Media System: Applying Technology Readiness and Technology Acceptance Model. International Journal of Information and Management Sciences, 30(1), 37-56.

Davis, F. D. (1989). Perceived usefulness, perceived ease of use, and user acceptance of information technology. MIS Quarterly, 319-340.

Davis, F. D. (1993). User acceptance of information technology: system characteristics, user perceptions and behavioral impacts. International Journal of Man-Machine Studies, 38(3), 475-487.

Davis, F. D., Bagozzi, R. P., \& Warshaw, P. R. (1989). User acceptance of computer technology: a comparison of two theoretical models. Management Science, 35(8), 982-1003.

Devaraj, S., Easley, R. F., \& Crant, J. M. (2008). Research note-how does personality matter? Relating the five-factor model to technology acceptance and use. Information Systems Research, 19(1), 93-105.

Díaz-García, M. C., \& Jiménez-Moreno, J. (2010). Entrepreneurial intention: the role of gender. International Entrepreneurship and Management Journal, 6(3), 261-283.

Do, B. R., \& Dadvari, A. (2017). The influence of the dark triad on the relationship between entrepreneurial attitude orientation and entrepreneurial intention: A study among students in Taiwan University. Asia Pacific Management Review, 22(4), $185-191$.

Douglas, E. J. (2013). Reconstructing entrepreneurial intentions to identify predisposition for growth. Journal of Business Venturing, 28(5), 633-651.

Eckhardt, J. T., \& Shane, S. A. (2003). Opportunities and entrepreneurship. Journal of Management, 29(3), 333-349.

Elston, J. A., \& Weidinger, A. (2018). Entrepreneurial intention and regional internationalization in China. Small Business Economics, 1-15.

Emirbayer, M., \& Goodwin, J. (1994). Network analysis, culture, and the problem of agency. American Journal of Sociology, 99(6), 1411-1454.

Engel, Y., Kaandorp, M., \& Elfring, T. (2017). Toward a dynamic process model of entrepreneurial networking under uncertainty. Journal of Business Venturing, 32(1), 35-51.

Hallen, B. L., \& Eisenhardt, K. M. (2012). Catalyzing strategies and efficient tie formation: How entrepreneurial firms obtain investment ties. Academy of Management Journal, 55(1), 35-70.

Hmieleski, K. M., \& Lerner, D. A. (2016). The dark triad and nascent entrepreneurship: An examination of unproductive versus productive entrepreneurial motives. Journal of Small Business Management, 54, 7-32.

Hoang, H., \& Antoncic, B. (2003). Network-based research in entrepreneurship: A critical review. Journal of Business Venturing, $18(2), 165-187$. 
Horst, M., Kuttschreuter, M., \& Gutteling, J. M. (2007). Perceived usefulness, personal experiences, risk perception and trust as determinants of adoption of e-government services in The Netherlands. Computers in Human Behavior, 23(4), $1838-1852$.

Horton, R. P., Buck, T., Waterson, P. E., \& Clegg, C. W. (2001). Explaining intranet use with the technology acceptance model. Journal of Information Technology, 16(4), 237-249.

Hughes, D. J., Rowe, M., Batey, M., \& Lee, A. (2012). A tale of two sites: Twitter vs. Facebook and the personality predictors of social media usage. Computers in Human Behavior, 28(2), 561-569.

Jelinek, M., \& Bird, B. (1988). The Operation of Entrepreneurial Intentions. Entrepreneurship Theory and Practice, 13, $21-29$.

Joo, J., \& Sang, Y. (2013). Exploring Koreans' smartphone usage: An integrated model of the technology acceptance model and uses and gratifications theory. Computers in Human Behavior, 29(6), 2512-2518.

Kaplan, A. M., \& Haenlein, M. (2010). Users of the world, unite! The challenges and opportunities of Social Media. Business Horizons, 53(1), 59-68.

Karimi, S., Biemans, H. J., Naderi Mahdei, K., Lans, T., Chizari, M., \& Mulder, M. (2017). Testing the relationship between personality characteristics, contextual factors and entrepreneurial intentions in a developing country. International Journal of Psychology, 52(3), 227-240.

Krueger Jr, N. F. (2007). What lies beneath? The experiential essence of entrepreneurial thinking. Entrepreneurship Theory and Practice, 31(1), 123-138.

Krueger Jr, N. F., Reilly, M. D., \& Carsrud, A. L. (2000). Competing models of entrepreneurial intentions. Journal of Business Venturing, 15(5-6), 411-432.

Kwon, O., \& Wen, Y. (2010). An empirical study of the factors affecting social network service use. Computers in Human Behavior, 26(2), 254-263.

Laroche, M., Habibi, M. R., Richard, M. O., \& Sankaranarayanan, R. (2012). The effects of social media based brand communities on brand community markers, value creation practices, brand trust and brand loyalty. Computers in Human Behavior, 28(5), $1755-1767$.

Lee, R. B., Baring, R., Maria, M. S., \& Reysen, S. (2017). Attitude towards technology, social media usage and grade-point average as predictors of global citizenship identification in Filipino University Students. International Journal of Psychology, 52(3), 213219.

Legris, P., Ingham, J., \& Collerette, P. (2003). Why do people use information technology? A critical review of the technology acceptance model. Information \& Management, 40(3), 191-204.

Leutner, F., Ahmetoglu, G., Akhtar, R., \& Chamorro-Premuzic, T. (2014). The relationship between the entrepreneurial personality and the Big Five personality traits. Personality and Individual Differences, 63, 58-63.

Liñán, F., \& Chen, Y. W. (2009). Development and Cross-Cultural application of a specific instrument to measure entrepreneurial intentions. Entrepreneurship Theory and Practice, 33(3), 593-617.

Liñán, F., Rodríguez-Cohard, J. C., \& Rueda-Cantuche, J. M. (2011). Factors affecting entrepreneurial intention levels: a role for education. International Entrepreneurship and Management Journal, 7(2), 195-218.

Lu, H. P., \& Hsiao, K. L. (2010). The influence of extro/introversion on the intention to pay for social networking sites. Information \& Management, 47(3), 150-157.

Mishra, C. S., \& Zachary, R. K. (2014). The Theory of Entrepreneurial Intentionality. In The Theory of Entrepreneurship (pp. 2148). Palgrave Macmillan, New York.

Moslehpour, M., Dadvari, A., Nugroho, W. and Do, B.-R. (2020). The dynamic stimulus of social media marketing on purchase intention of Indonesian airline products and services, Asia Pacific Journal of Marketing and Logistics, Vol. ahead-of-print No. ahead-of-print. https://doi.org/10.1108/APJML-07-2019-0442

Moslehpour, M., Thanh, H.L.T., Pham, V.K. (2018). Technology Perception, Personality Traits and Online Purchase Intention of Taiwanese Consumers. In: Kreinovich V., Sriboonchitta S., Chakpitak N. (eds) Predictive Econometrics and Big Data. TES 2018. Studies in Computational Intelligence, 753, 392-407. Springer, Cham. doi:10.1007/978-3-319-70942-0_28

Shamuganathan, G., \& Nga, J. K. H. (2010). The Influence of Personality Traits and Demographic Factors on Social Entrepreneurship Start Up Intentions. Journal of Business Ethics, 95(2), 259-282.

Ngai, E. W., Tao, S. S., \& Moon, K. K. (2015). Social media research: Theories, constructs, and conceptual frameworks. International Journal of Information Management, 35(1), 33-44.

Obschonka, M., Silbereisen, R. K., Cantner, U., \& Goethner, M. (2015). Entrepreneurial self-identity: predictors and effects within the theory of planned behavior framework. Journal of Business and Psychology, 30(4), 773-794.

Obschonka, M., Silbereisen, R. K., \& Schmitt-Rodermund, E. (2010). Entrepreneurial intention as developmental outcome. Journal of Vocational Behavior, 77(1), 63-72.

Obschonka, M., Zhou, M., Zhou, Y., Zhang, J., \& Silbereisen, R. K. (2019). "Confucian” traits, entrepreneurial personality, and entrepreneurship in China: a regional analysis. Small Business Economics, 53(4), 961-979.

Ones, D. S., Dilchert, S., Viswesvaran, C., \& Judge, T. A. (2007). In support of personality assessment in organizational settings. Personnel Psychology, 60(4), 995-1027.

Park, E., \& Kim, K. J. (2014). An integrated adoption model of mobile cloud services: exploration of key determinants and extension of technology acceptance model. Telematics and Informatics, 31(3), 376-385.

Park, N., Rhoads, M., Hou, J., \& Lee, K. M. (2014). Understanding the acceptance of teleconferencing systems among employees: An extension of the technology acceptance model. Computers in Human Behavior, 39, 118-127.

Peterman, N. E., \& Kennedy, J. (2003). Enterprise education: Influencing students' perceptions of entrepreneurship. Entrepreneurship Theory and Practice, 28(2), 129-144.

Porter, C. M., \& Woo, S. E. (2015). Untangling the networking phenomenon: A dynamic psychological perspective on how and why people network. Journal of Management, 41(5), 1477-1500. 
Pourkhani, A., Abdipour, Kh., Baher, B. and Moslehpour, M. (2019). The impact of social media in business growth and performance: A scientometrics analysis, International Journal of Data and Network Science 3(3), 223-244.

Preacher, K. J., \& Hayes, A. F. (2004). SPSS and SAS procedures for estimating indirect effects in simple mediation models. Behavior Research Methods, Instruments, \& Computers, 36(4), 717-731.

Roberts, B. W. (2009). Back to the future: Personality and assessment and personality development. Journal of Research in Personality, 43(2), 137-145.

Podsakoff, P. M., MacKenzie, S. B., Lee, J. Y., \& Podsakoff, N. P. (2003). Common method biases in behavioral research: A critical review of the literature and recommended remedies. Journal of Applied Psychology, 88(5), 879-903.

Ross, C., Orr, E. S., Sisic, M., Arseneault, J. M., Simmering, M. G., \& Orr, R. R. (2009). Personality and motivations associated with Facebook use. Computers in Human Behavior, 25(2), 578-586.

Ryan, T., \& Xenos, S. (2011). Who uses Facebook? An investigation into the relationship between the Big Five, shyness, narcissism, loneliness, and Facebook usage. Computers in Human Behavior, 27(5), 1658-1664.

Schlaegel, C., \& Koenig, M. (2014). Determinants of Entrepreneurial Intent: A Meta-Analytic Test and Integration of Competing Models. Entrepreneurship Theory and Practice, 38(2), 291-332.

Schmidthuber, L., Maresch, D., \& Ginner, M. (2020). Disruptive technologies and abundance in the service sector-toward a refined technology acceptance model. Technological Forecasting and Social Change, 155, 119328.

Shinnar, R. S., Hsu, D. K., Powell, B. C., \& Zhou, H. (2018). Entrepreneurial intentions and start-ups: Are women or men more likely to enact their intentions?. International Small Business Journal, 36(1), 60-80.

Shook, C. L., Ketchen Jr, D. J., Hult, G. T. M., \& Kacmar, K. M. (2004). An assessment of the use of structural equation modeling in strategic management research. Strategic Management Journal, 25(4), 397-404.

Slotte-Kock, S., \& Coviello, N. (2010). Entrepreneurship research on network processes: A review and ways forward. Entrepreneurship Theory and Practice, 34(1), 31-57.

Soto-Acosta, P., Popa, S., \& Palacios-Marqués, D. (2017). Social web knowledge sharing and innovation performance in knowledgeintensive manufacturing SMEs. The Journal of Technology Transfer, 42(2), 425-440.

Stuetzer, M., Obschonka, M., \& Schmitt-Rodermund, E. (2013). Balanced skills among nascent entrepreneurs. Small Business Economics, 41(1), 93-114.

Sun, H., \& Zhang, P. (2008). An exploration of affect factors and their role in user technology acceptance: Mediation and causality. Journal of the American Society for Information Science and Technology, 59(8), 1252-1263.

Svendsen, G. B., Johnsen, J. A. K., Almås-Sørensen, L., \& Vittersø, J. (2013). Personality and technology acceptance: the influence of personality factors on the core constructs of the Technology Acceptance Model. Behaviour \& Information Technology, 32(4), 323-334.

Tess, P. A. (2013). The role of social media in higher education classes (real and virtual)-A literature review. Computers in Human Behavior, 29(5), A60-A68.

Wang, C. K., \& Wong, P. K. (2004). Entrepreneurial interest of university students in Singapore. Technovation, 24(2), 163-172.

Wang, Y. S., Wang, Y. M., Lin, H. H., \& Tang, T. I. (2003). Determinants of user acceptance of Internet banking: an empirical study. International Journal of Service Industry Management, 14(5), 501-519.

Wennekers, S., \& Thurik, R. (1999). Linking entrepreneurship and economic growth. Small Business Economics, 13(1), $27-56$.

Wu, Y. C. J., Pan, C. I., \& Yuan, C. H. (2017). Attitudes towards the use of information and communication technology in management education. Behaviour \& Information Technology, 36(3), 243-254.

Zaremohzzabieh, Z., abu Samah, B., Muhammad, M., Omar, S. Z., Bolong, J., Hassan, M. S., \& Shaffril, H. A. M. (2015). A test of the technology acceptance model for understanding the ICT adoption behavior of rural young entrepreneurs. International Journal of Business and Management, 10(2), 158.

Zaremohzzabieh, Z., Samah, B. A., Muhammad, M., Omar, S. Z., Bolong, J., Hassan, S. B. H., \& Mohamed Shaffril, H. A. (2016). Information and communications technology acceptance by youth entrepreneurs in rural Malaysian communities: The mediating effects of attitude and entrepreneurial intention. Information Technology for Development, 22(4), 606-629.

Zhang, X., Gao, Y., Yan, X., de Pablos, P. O., Sun, Y., \& Cao, X. (2015). From e-learning to social-learning: Mapping development of studies on social media-supported knowledge management. Computers in Human Behavior, 51, 803-811.

Zhang, X., Ma, L., Xu, B., \& Xu, F. (2019). How social media usage affects employees' job satisfaction and turnover intention: An empirical study in China. Information \& Management, 56(6), 103136.

Zhang, Y., Duysters, G., \& Cloodt, M. (2014). The role of entrepreneurship education as a predictor of university students' entrepreneurial intention. International Entrepreneurship and Management Journal, 10(3), 623-641.

Zhao, H., \& Seibert, S. E. (2006). The Big Five personality dimensions and entrepreneurial status: A meta-analytical review. Journal of Applied Psychology, 91(2), 259.

Zhao, H., Seibert, S. E., \& Lumpkin, G. T. (2010). The relationship of personality to entrepreneurial intentions and performance: A meta-analytic review. Journal of Management, 36(2), 381-404.

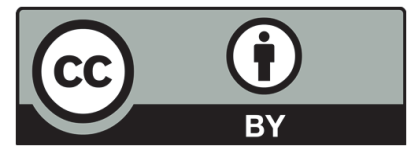

(C) 2020 by the authors; licensee Growing Science, Canada. This is an open access article distributed under the terms and conditions of the Creative Commons Attribution (CC-BY) license (http://creativecommons.org/licenses/by/4.0/). 